\title{
The Impacts of Deceptive Advertising on Women Consumer
}

\author{
Nafisa Newaz (Lecturer) \\ Department of Business Administration, \\ BGMEA University of Fashion \& Technology, Dhaka, Bangladesh
}

Doi: 10.19044/esj.2017.v13n35p302 URL:http://dx.doi.org/10.19044/esj.2017.v13n35p302

\begin{abstract}
Every day, consumers are exposed to hundreds of commercial messages. The ultimate goal of advertising is to robustly attract consumers by giving them product-related information, application of the products, demonstrate the uses of the products, and guide them to purchase the products. It is absolutely necessary to ensure that consumers perceive advertising as something positive and not otherwise. Consumers' positive attitudes towards advertising can generate profit for companies, and that is only if advertising can promote products that the consumers needs. Advertising should follow ethical guidelines. Some actions that are quite unethical include women exploitation, influencing consumers to buy a product without providing them with adequate knowledge on what is to be bought, and deceptive advertising, involving false claims and other issues which could lead to moral deterioration of the society. This paper is an effort to find out the impacts of these types of deceptive advertisements on women.
\end{abstract}

Keywords: Deceptive advertising, social, health, impact, women

\section{Introduction}

Advertising is one of the most popular means of promotion which works by providing message or information about products. It is one unbeatable promotional tool which spurs more sales or promotes a product, service, or idea. The advertising landscape is currently more challenging than ever before, due to more informed consumers, creative copy writing skills, higher competition, and technological advancement. Various consumers are accustomed to watching different forms of media; the manner of presentation of the advertisements often triggers in the consumers experiences of a variety of feelings. Men and women respond to different stimuli and in different ways too, are captivated by different details and also relate differently to various advertising media as well. Since women represent about 85 percent 
of consumer shopping, amounting to about $\$ 4$ trillion of purchases per year according to the Women Certified website, they are therefore a valuable group to target. So, in order to target and attract them, many companies have resorted into cheap misleading advert contents and campaigns, which in turn hampers our day to day life.

Amongst consumer goods industries, firms who advertise are less likely to exit from the market due to the higher reception they enjoy than those who do not advertise (Paton \& William, 1999).

Deceptive advertising is officially defined by the Federal Trade Commission (FTC) as "a representation, omission or practice that is likely to mislead the consumer" and "practices that have been found misleading or deceptive in specific cases include false oral or written representations, misleading price claims, sales of hazardous or systematically defective products or services without adequate disclosures, failure to disclose information regarding pyramid sales, use of bait and switch techniques, failure to perform promised services, and failure to meet warranty obligations."

Women's feminine attitudes regarding physical attractiveness relate significantly to body satisfaction, but an overall feministic identification does not (Dionne, Davis, Fox \& Gurevich, 1995). Those in the business of making beautification products do not need to contradict genuine feminine concerns in the bid to exploit them. However, they ought to endeavor to explore better ways that hold actual promise of beautification in a manner that leads women to attain an improved self-awareness and understanding of one's self (Cahill, 2003).

The sort of information that is sought on beautification products and the manner in which they are used by students from higher learning institutions are highly influenced by factors such as friends, the internet, magazines, beauty parlor/salon, product brand, siblings, social network, manufacturing countries, parents, enclosed leaflets, newspapers and the radio (Massoro, 2006).

According to a report, the Indian whitening cream market is expanding on a rate of nearly $18 \%$ each year. The country's largest research agency, AC Nielsen, estimates that the figure will rise to about $25 \%$ this year - the market will be worth an estimated $\$ 432 \mathrm{~m}$, an all-time high.

Modern day women in America are now keener on taking greater care of their faces and skin health than ever before: the average 'worth' or value of a woman's face costs about $\$ 8$ per day. This is boosted by the shocking revelation that $85 \%$ of women apply an average of 16 skin cares and cosmetic products every day. Figures show that, per day, $\$ 5$ of the average face spent goes to the skincare products used, and another $\$ 3$ on makeup (Johnson, 2017). 
Female beauty endorsers draw buyers' attention and thereby increase the advertising effect (Lin \& Yeh, 2009).

The relationship between ad exposure and consumption is greater for women than men (Cohan, 2001).

Many side effects have been associated with the use of beautification products like dandruff, skin irritation, hair loss, allergic reaction, thinning eyelashes, skin cancer, hair breakage, aging and wrinkling of skin etc. (Massoro, 2006). Yet, report shows that beautification products are highly selling products (The Weekend Leader, 2009).

\section{Rationale for Choosing the Topic}

Deceptive advertisements could mislead consumers by spurring them to spend more money on a product or service or by exposing them to the risk of injury through false claims about health or safety. These sorts of unethical practices cause harm to people in many ways. One of such ways is by causing serious health diseases. Therefore, we can categorically say it causes harm by creating threat to human health security, by causing economic instability, and by degrading social values.

a) Creating Threat to Human Health: In recent years, there has been the trend of introducing women to weight reduction or fat burning means. Those types of advertising mostly make unproven claims that eating certain foods can improve health and even reduce the risk of serious illnesses or burn fat. In contrast, such chemicals are responsible for illnesses like prostate cancer and heart diseases. Even most creams sold in the market have been found to contain compounds like steroids, hydroquinone, and tretinoin, and they cause very dangerous effects on the user. An example is the after effect of such compounds notorious for producing lethal health issues, such as permanent pigmentation.

b) Economic Instability: Deceptive marketing can likewise harm competitors and the business itself by causing a long term loss of business and products. This is because they are generally ineffective and comes with potential serious side effects. Deceptive advertising influences women to spend more and buy such kind of products. Thus, it reduces their savings. Either indirectly or directly, it minimizes their budget spent on basic needs to the detriment of their financial plan. It also leads women towards increasing their compulsive buying tendency towards such products.

c) Degrading Social Values: The matrimonial market gives preference to fair looking girls. Racism and the stigma associated with dark skin, as it were, have gone profoundly deep into our psychology. As a result, young girls of today are crazily investing into the purchase of 
whitening creams without taking into due consideration the side effects of such products. The manufacturers of these creams make the most of the consumers' psychological obsession by enticing them with eye-catching advertisements. Here, they get to see their favorite movie stars on television endorsing a particular fairness cream, with an attached false claim that using it would turn one fair. These promotions are done in such captivating ways which is enough for them to give in to the enticement. Ultimately, this has a significant impact on their social perspectives.

\section{Objectives of the Study}

The main objective of the study is to know the impacts of deceptive advertising on women consumers.

1. To identify the health impact of deceptive advertisement on women consumers.

2. To identify the social impact of deceptive advertisement on women consumers.

3. To provide recommendations for avoiding deceptive advertisements.

\section{Data and Evidence}

The Primary data were collected through the five point likert scale structured questionnaire. This empirical research, based on questionnaire survey, has been carried out on convenience sampling of women in Dhaka region (capital of Bangladesh) in the age group of 20-40 years. Questionnaires were designed in the light and context of the objectives of the study. A total of 80 questionnaires were purposively circulated through email to women who serve at different universities, at private organizations, as home makers and as students being the respondents of the questionnaire. 60 of the questionnaires were returned and fully answered.

Secondary data was collected from books, journal articles, internet sites, reports and newspapers.

Table 1. Showing Deceptive Advertising Scores

\begin{tabular}{|c|c|}
\hline $\begin{array}{c}\text { Score Range / } \\
\text { Implications }\end{array}$ & Score \\
\hline Maximum Score & 25 \\
\hline Minimum Score & 5 \\
\hline Neutral & 15 \\
\hline Neutral Mean & 3.00 \\
\hline
\end{tabular}


Table 2. Mean, Median, Mode of all the variables of social impact and health impact

\begin{tabular}{|c|c|c|c|c|c|c|c|c|}
\hline & $\begin{array}{c}\text { Stereoty } \\
\text { pe role }\end{array}$ & $\begin{array}{l}\text { Affectin } \\
\mathrm{g} \\
\text { lifestyle }\end{array}$ & $\begin{array}{c}\text { Failed } \\
\text { promised } \\
\text { services }\end{array}$ & $\begin{array}{c}\text { Social } \\
\text { disappro } \\
\text { val }\end{array}$ & $\begin{array}{l}\text { Side } \\
\text { effect }\end{array}$ & $\begin{array}{l}\text { Manage } \\
\text { my own } \\
\text { health } \\
\text { care }\end{array}$ & $\begin{array}{l}\text { Unaware } \\
\text { of the } \\
\text { conseque } \\
\text { nce of } \\
\text { products }\end{array}$ & $\begin{array}{l}\text { Like to } \\
\text { follow } \\
\text { the brand } \\
\text { ambassa } \\
\text { dor }\end{array}$ \\
\hline Vali & 60 & 60 & 60 & 60 & 60 & 60 & 60 & 60 \\
\hline $\begin{array}{c}\text { Miss } \\
\text { ing }\end{array}$ & 0 & 0 & 0 & 0 & 0 & 0 & 0 & 0 \\
\hline Mean & 3.12 & 3.00 & 3.40 & 3.17 & 3.23 & 3.07 & 3.13 & 2.97 \\
\hline Median & 3.00 & 3.00 & 4.00 & 3.00 & 4.00 & 3.00 & 3.00 & 3.00 \\
\hline Mode & 4 & 4 & 4 & 4 & 4 & 4 & 4 & 3 \\
\hline $\begin{array}{c}\text { Std. } \\
\text { Deviation }\end{array}$ & 1.059 & 1.089 & 1.108 & 1.092 & 1.170 & 1.023 & 1.049 & 1.008 \\
\hline
\end{tabular}

This table shows the descriptive statistics of variables. It shows the mean score of the selected variables. Here, the highest mean score, which is 3.40 and is above the neutral mean score of 3 , indicates that majority of the users of beautification products are in agreement with the statement that products failed to meet the promised services. The mean value of side effects is 3.23. More than an average of the consumers faced health problems after using those products. Some who have faced minimum health problems were found to have stopped using those products.

Mean value of following a brand ambassador is 2.97 . Thus, less than an average of the respondents agree that seeing the model or brand ambassador on screen during a commercial advertisement causes them to visualize themselves becoming like those models. We can thus infer that celebrity endorsers draw the consumers' attention through advertisement; but users or customers themselves are responsible for getting the information about the product. Most consumers don't buy beautification products or weight reducing and fat burning products by seeing the brand ambassador only; rather, they go in search for more information. If the information obtained is good enough and appears to be able to satisfy their need, they take the positive approach of buying.

According to the report of The Weekend Leader, cosmetic industries are well aware of this fact and have alongside with clever advertising created a platform whereby they provide 'amazing' solutions to supposedly unpleasant situations. With a blitz of messages formulated around fear, the consumer is trapped in a maze of timidity. More than an average of the consumers agrees that deceptive advertising creates misperception that ultimately impacts their social thinking and social conscience. The mean value 3.17 says that deceptive advertising creates social disapproval of dark skin and fat women. The mean value for been unaware of the consequence of 
products is 3.13: this means that, when buying a product, consumers tend to relate their need with the products in an uninformed way, without giving much concern about the product's after-use negative consequences. The mean of portraying Stereotype role is 3.12. That shows that more than an average of the consumers agree that the advertising of fat burning health care products and beautification products are used to show the stereotyped role of women in their advertisement. It depict that women should focus on beautifying themselves, and that if they use these products, they can place themselves in the matrimonial market and get a handsome and a well established husband. Mean value 3.07 of managing one's own health care indicates that women are mostly neutral in the case of managing their own health care rather than visiting a doctor. The neutral value 3.00 indicates that women are neutral whether these advertisements have any impact on lifestyle or not.

\section{Hypothesis 1}

Null Hypothesis,

$\mathrm{H} 0=$ There is no social impact of deceptive advertisement on women

Alternate Hypothesis,

$\mathrm{H} 1=$ There is social impact of deceptive advertisement on women

Table 3. Correlations of the variables of social impact

\begin{tabular}{|c|c|c|c|c|c|}
\hline & & $\begin{array}{l}\text { Stereotype } \\
\text { role }\end{array}$ & $\begin{array}{l}\text { Affecting } \\
\text { lifestyle }\end{array}$ & $\begin{array}{c}\text { Social } \\
\text { disapproval }\end{array}$ & $\begin{array}{l}\text { Like to follow } \\
\text { the brand } \\
\text { ambassador }\end{array}$ \\
\hline Advertising & Pearson Correlation & 1 & $837^{* *}$ & $.789^{* *}$ & $.686^{* *}$ \\
\hline portrays & Sig. (2-tailed) & & .000 & .000 & .000 \\
\hline Stereotype role & $\mathrm{N}$ & 60 & 60 & 60 & 60 \\
\hline & Pearson Correlation & $.837^{* *}$ & 1 & $.784^{* *}$ & $.834^{* *}$ \\
\hline Affecting & Sig. (2-tailed) & .000 & & .000 & .000 \\
\hline & $\mathrm{N}$ & 60 & 60 & 60 & 60 \\
\hline & Pearson Correlation & $.789^{* *}$ & $784^{* *}$ & 1 & $.760^{* *}$ \\
\hline disannroval & Sig. (2-tailed) & .000 & .000 & & .000 \\
\hline & $\mathrm{N}$ & 60 & 60 & 60 & 60 \\
\hline & Pearson Correlation & $.686^{* *}$ & $.834^{* *}$ & $.760^{* *}$ & 1 \\
\hline Like to follow & Sig. (2-tailed) & .000 & .000 & .000 & \\
\hline & $\mathrm{N}$ & 60 & 60 & 60 & 60 \\
\hline
\end{tabular}

From the table, we can see that there is a positive moderate to strong linear relationship between all the variables that are responsible for causing social impact. Here, the $\mathrm{P}$ value is less than .01 . The test is significant at a $1 \%$ level of significance. Therefore, we can reject the null hypothesis and accept the alternate hypothesis, which states that deceptive advertising causes social impact. 


\section{Hypothesis 2}

Null Hypothesis,

$\mathrm{H} 0=$ There is no health impact of deceptive advertisement on women

Alternate Hypothesis, consumers

$\mathrm{H} 1=$ There is health impact of deceptive advertisement on women consumers.

Table 4. Correlations of the variables of health impact

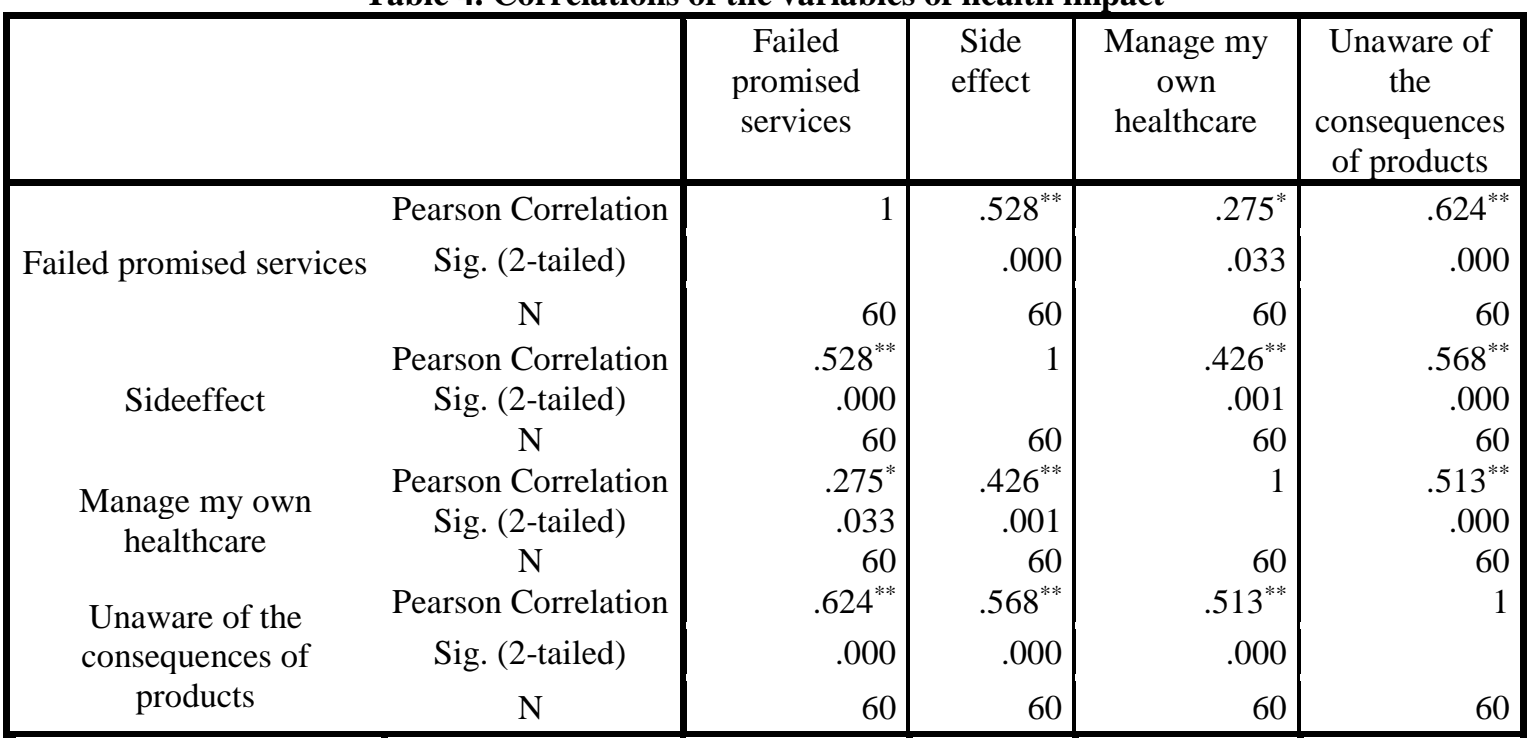

**. Correlation is significant at the 0.01 level (2-tailed).

*. Correlation is significant at the 0.05 level (2-tailed).

From the table, we can see that there is a positive weak to strong linear relationship between all the variables that are responsible for causing health impact. Here, the $\mathrm{P}$ value is less than .05 . The test is significant at a $5 \%$ level of significance. Therefore, we can reject the null hypothesis and accept the alternate hypothesis, which states that deceptive advertising causes health impact.

Women are the most lucrative segment of the society for targeting. Thus, beautification products are basically targeted at women and, as a result, physical attractiveness (beauty, body form, posture, and sex appeal) basically becomes all about getting bodily exposed. Women, in particular, can suffer some serious psychological depressions from the subtle and general effects of advertising aimed at them. Asides body weight issues, advertisements often depict very young and unbelievably beautiful women. As women get older, they feel an overwhelming pressure to look young again, ignoring their natural beauty. Then these women get indoctrinated that beauty will give them a crest. This causes a form of degradation of social 
values. According to DiscoverYourDaughter.com, many ads present consequence-free scenarios of beautiful people enjoying, say, junk food or video games. Such images imply that one can lead a healthy way of life by purchasing such products, when in actuality, the reverse is often true. When coupled with other images presented to women about slimming, youthfulness and sexuality, it creates a dangerous imagination that such a lifestyle is achievable or more preferred, when in fact such feeling is a result of low self-approval/esteem and often leads to negative habits.

\section{Limitation}

In this paper, the selected sample age is between 20 to 40 years. If data were collected from another age group, a different result may come out. This study was conducted with a small sample size. The same type of study may be conducted with a larger sample size by using different methodology and at a different site.

\section{Conclusion}

From this survey, it was shown that women get attracted by the celebrity that act as brand model, but in actual case of buying, they don't only consider brand ambassador. They give priority to the advertising information about the product. They like to verify what the products promised to offer. Nevertheless, most of these products fail to keep their promises, which then results in deceptive advertisement. Deceptive advertisement, thus, gives some misperception to girls. In the bid to secure a social status, most of the women get to pay more to buy those products by cutting on other budget money to their losses. The proper implementation of consumer protection laws to discourage misleading advertisement can be a solution to this trend. On the other hand, if no consumer actually files a lawsuit, ads often go unchallenged. For larger corporations that can indeed meet the expenses of the occasional lawsuits, the payoff is often well worth the risk of running an ad that toes the line. Deceptive advertising has led to increased spending on these products, as consumers attempt to self-manage their own healthcare and escape expensive visits to doctors and medical prescription. The health claims made for these products are false or unproven. I hereby recommend that women consumers be protected from these deceptive advertising and as well be kept safe from the negative impact of the same products by educating consumers the more, providing them with the knowledge that there is such a thing as "consumer rights". Companies can encourage their creative teams to transform negative images to ones which empower women. However, this can be done by painting women as human beings with brains and with a rational will, rather than portraying women as "kits." Awareness can also be created. Social networking sites can 
be a most powerful platform for articulating the side effects of these products and their false claims.

\section{References:}

1. Cahill, A.J. (2003). Feminist pleasure and feminine beautification. Hypatia, 18(4), pp.42-64.

2. Cohan, J.A. (2001). Towards a new paradigm in the ethics of women's advertising. Journal of Business Ethics, 33(4), pp.323-337.

3. Deceptive Advertisements. Protecting Consumers \& Businesses from Deceptive Advertising \& Marketing. Retrieved from https://www.girardgibbs.com/consumer-protection/falseadvertising/deceptive-advertising/

4. Dionne, M., Davis, C., Fox, J., \& Gurevich, M. (1995). Feminist ideology as a predictor of body dissatisfaction in women. Sex Roles, 33(3), pp.277-287.

5. Lin, C. L., \& Yeh, J. T. (2009). Comparing society's awareness of women: Media-portrayed idealized images and physical attractiveness. Journal of Business Ethics, 90(1), 61-79.

6. Paton, D. \& Williams, L.V. (1999). Advertising and firm performance: some new evidence from UK firms. Economic Issues, 4(2), pp.89-105.

7. Sissi Johnson (2017). "How much is your face worth? American women average at $\$ 8$ per day".

8. "The weekend leader (2009). The Indian whitening cream market is expanding at a rate of nearly $18 \%$ a year. Retrieved from http://www.theweekendleader.com/Causes/1249/scare-and-sell.html

9. Zainabu Zuberi Massoro (2006). Information Seeking and Use Behaviour on Beautification Product among Students of Higher Learning Institutions 24 (1). pp 149-156. 